\title{
Congenitally short costocoracoid ligament
}

INSERM

\section{Source}

INSERM. (1999). Orphanet: an online rare disease and orphan drug data base.

Congenitally short costocoracoid ligament. ORPHA:2391

Congenital shortness of the costocoracoid ligament is a rare anomaly characterized by fixation of the scapula to the first rib, resulting in a cosmetic deformity with rounding of the shoulders and loss of the anterior clavicular contour. 